FITRAH Jurnal Kajian Ilmu-ilmu Keislaman

Vol. 05 No. 1 Juni 2019

e-ISSN : 2460-2345, p-ISSN: 2442-6997

Web: jurnal.iain-padangsidimpuan.ac.id/index.php/F

\title{
PENDEKATAN SISTEM DALAM TEORI HUKUM ISLAM (Perspektif Jasser Auda)
}

\author{
ILHAM MASHURI \\ Institut Agama Islam Negeri Kediri \\ Email: medyna.ilham@gmail.com
}

\begin{abstract}
The main problem in the development of Islamic law is the failure to distinguish between nash and tafsir, strong atomistic approach, and binary. Instead of contributing to the contemporary problems, it is confined in right or wrong polemic, cause and effect, qath'i zhani, male and Female; rejecting the role of other sciences (science, social science, philosophy) in the development of Islamic law. Through a system approach, Jasser Auda offers a "multidimensional" approach and a more holistic approach. The Auda's system approach is in line with the objectives of Islamic law or realizing the maqasid by maintaining openness, renewal, and even the validity of ijtihad must be measured to the extent that it realizes the maqasid.
\end{abstract}

Keywoards: Maqasid, System Theory, Islamic Law

\begin{abstract}
Abstrak
Problem utama dalam pengembangan hukum Islam adalah gagalnya membedakan antara nash dan tafsir, kuatnya pendekatan atomistik, dan biner. Alih-alih berkontribusi terhadap masalah-masalah kontemporer, ia terkurung dalam polemik benar salah, sebab-akibat, qath'i zhani, lakilaki perempuan; menolak peran ilmu lain (sains, ilmu sosial, filsafat) dalam pengembangan hukum Islam. Melalui pendekatan sistem, Jasser Auda menawarkan pendekatan yang lebih bersifat 'multidimensional" dan pendekatan yang lebih "utuh". Pendekatan sistem Auda selaras dengan tujuan hukum Islam atau merealisasikan maqasid dengan menjaga keterbukaan, pembaharuan, bahkan keabsahan ijtihad harus diukur sejauhmana ia merealisasikan maqasid.
\end{abstract}

Kata Kunci: Maqasid, Teori Sistem, Hukum Islam.

\section{PENDAHULUAN}

Persoalan utama yang kini dihadapi oleh umat Islam adalah nihilnya worldview keagamaan yang utuh (komprehensif) dalam melihat persoalanpersoalan kontemporer yang melaju kencang bersamaan dengan perkembangan sosial dan teknologi. Dunia Islam masih sibuk dengan perbedaan mazhab yang 
FITRAH Jurnal Kajian Ilmu-ilmu Keislaman

Vol. 05 No. 1 Juni 2019

meruncing (Sunni-Syi'ah), kemiskinan, perang saudara, dan rendahnya indeks pertumbuhan manusia. ${ }^{1}$ Atau dalam bahasa lain cara berpikir biner, benar-salah, qath'i-zhanni, masih mengungkung pemikiran mayoritas umat Islam, sehingga mereka sulit berinteraksi dengan dunia global yang terus bergerak sangat cepat. Inilah tradisi keilmuan yang berkembang di dunia Islam.

Di sini lain di negara-negara yang mayoritas penduduknya non muslim telah melesat jauh. Terjadi perkembangan ilmu pengetahuan, tatanan sosialpolitik dan sosial-ekonomi, hukum, tata kota, lingkungan hidup dan begitu seterusnya. Secara spesifik perubahan tersebut menyangkut, migrasi penduduk, kemajuan sains dan teknologi, eksplorasi ruang angkasa, penemuan-penemuan arkeologis, evolusi, dan genetika.

Di sinilah pentingnya mempertemukan kedua tradisi keilmuan tersebut. Jika pada era sebelumnya pemikiran biner sangat mendominasi, sehingga antara Islam dan Barat sulit dipertemukan, pada era ini perlu pendekatan baru, sehingga umat Islam bisa berpartisipasi dan berkontribusi terhadap perkembangan global yang berjalan sangat cepat. Pendekatan biner tidak lagi memadai untuk memecahkan masalah-masalah global tersebut. Melalui teori sistem, alam semesta ini merupakan struktur yang kompleks, dan struktur ini tidak bisa didekati dengan pendekatan sebab-akibat, namun harus didekati dengan kesalingterkaitan, dan keutuhan antar bagian-bagian alam. Begitu juga dengan hukum Islam, harus dilihat sebagai sesuai utuh dan saling terkait. ${ }^{2}$ Melalui teori ini Auda mempertanyakan kembali tentang peran maqasid syari'ah sebagai metode ijtihad? Bagaimana cara kerja teori sistem dalam bidang fikih? Bagaimana kita menggunakan filsafat sistem Islam dalam teori hukum Islam, untuk menjadikan hukum Islam bisa diperbaharui dan hidup? Bagaimana kelemahankelemahan teori hukum klasik, modern dan postmodern dicoba carikan jalan keluar melalui teori sistem?

\section{KAJIAN TEORI}

\section{Biografi}

Jasser Auda adalah Associate Professor di Fakultas Studi Islam Qatar dengan fokus kajian Kebijakan Publik dalam program Studi Islam. Dia adalah

${ }^{1}$ Jasser Auda, Maqasid al-Syariah as Philosophy of Islamic Law: a Systems Approach (London: The International Institute of Islamic Thought, 2008), hlm. xxii.

${ }^{2}$ Jasser Auda, Maqasid..., hlm. 29 
anggota pendiri Persatuan Ulama Muslim Internasional, yang berbasis di Dublin; anggota Dewan Akademik Institut Internasional Pemikiran Islam di London, Inggris; anggota Institut Internasional Advanced Sistem Research (IIAS), Kanada; anggota pengawas Global Pusat Studi Peradaban (GCSC), Inggris; anggota Dewan Eksekutif Asosiasi Ilmuan Muslim Sosial (AMSS), Inggris; anggota Forum perlawanan Islamofobia dan Racism (FAIR), Inggris dan konsultan untuk Islamonline.net. Ia memperoleh gelas Doktor dari University of Wales, Inggris, pada konsentrasi Filsafat Hukum Filsafat Hukum Islam di London, Inggris, dan menjadi dosen tamu untuk Fakultas Hukum Universitas Alexandria, Mesir, Islamic Institute of Toronto, Kanada dan Akademi Fiqh Islam, India. Dia menjadi dosen mata kuliah hukum Islam, Filsafat, dan materi yang terkait dengan isu-isu minoritas Muslim dan Kebijakan di beberapa negara di seluruh dunia. Jasser Auda telah menulis sejumlah buku, yang terakhir dalam bahasa Inggris, berjudul Maqasid alSyariah as Philosophy of Islamic Law: A Systems Approach, London: IIT, 2008. Tulisan yang telah diterbitkan sejumlah 8 buku dan ratusan tulisan dalam bentuk jurnal, tulisan media, kontribusi tulisan di buku, DVD, ceramah umum, dan jurnal online yang tersebar di seluruh dunia. Selain itu, banyak penghargaan yang telah ia terima. ${ }^{3}$

Biografi di atas menjelaskan bagaimana kegelisahan akademik seorang Jasser Auda ketika bergumul dalam persoalan ijtihad dan jihad berpikir untuk memperbaharui dan mengembangkan teon hukum Islam tradisional. Ia ingin menyumbangkan keahlian dan keilmuannya untuk membantu rekan-rekannya yang menghadapi jalan buntu mtelektual ketika hendak membuka pintu ijtihad, karir akademiknya pun ia rancang sedemikian terprogram sejak dan mulai menguasai bidang Figh, Usul al-Figh, Hukum Islam, teori Maqasid sampai menguasai teori Sistem ${ }^{4}$ dengan baik pada tingkat doktor Sekumpulan pengetahuan dengan berbagai pendekatan inilah yang ia himpun untuk menunjang karir akademiknya yang telah lama ia idam-idamkan untuk membantu membuka kembali pintu ijtihad yang telah lama terbuka, tapi tidak

\footnotetext{
${ }^{3}$ Lebih jauh tentang Jasser Auda bisa ditemukan dalam www.jasserauda.net dan juga www.maqasid.net

4 Sistem adalah bidang ilmu (baru) mandiri yang mencakup beberapa sub disiplin, di antaranya teori sistem dan analisis sistem. Teori sistem adalah pendekatan filosofis anti modernis yang mengkritik modernisme sedemikian rupa yang berbeda dengan teori posmodernisme. Beberapa konsep yang diambil dari teori sistem dipergunakan oleh Jasser Auda untuk mengembangkan hukum Islam, seperti wholeness, mutlidimensionality, openness, dan purposefulness, Jasser Auda, Maqasid .., xxvi
} 
FITRAH Jurnal Kajian Ilmu-ilmu Keislaman

Vol. 05 No. 1 Juni 2019

ada yang berani masuk. ${ }^{5}$. Melalui maqasid, Jasser Auda Jasser Auda menekankan pada aspek pendekatan yang lebih bersifat "multidimensional" (Multidimensional) dan pendekatan yang lebih "utuh-menyeluruh" (Holistic approach) terhadap hukum Islam. ${ }^{6}$ Audah mendefinisikan hukum Islam sebagai sistem yang memiliki tujuan merealisasikan maqasid syari'ah. ${ }^{7}$ Dengan demikian posisi maqasid syari'ah menempati posisi yang sangat penting dalam hukum Islam. Namun ketika dikaji secara mendalam klasifikasi atau kategorisasi maqasid yang dibuat oleh ulama, baik klasik maupun kontemporer, tidak satupun yang mengklaim maqasid-nya paling sesuai dengan Kehendak Tuhan, sehingga semuanya adalah produk ilmu pengetahuan dan hasil karya manusia. ${ }^{8}$

\section{PEMBAHASAN}

\section{Maqasid Baru Dalam Hukum Islam}

Setelah mengkaji maqasid klasik, Auda menawarkan maqasid baru sebagai berikut:

a. Perluasan terhadap maqasid

Maqasid dalam teori hukum Islam klasik terbatas pada kemaslahan individu, menurut Auda harus diperluas dimensinya, sehingga mencakup wilayah yang lebih umum; dari wilayah individu menjadi wilayah masyarakat atau umat manusia dengan segala tingkatannya. Dari perlindungan keturunan (hifz an-nasl) menjadi perlindungan keluarga (hifz al-usrah); dari perlindungan akal (hifz al-aql) menjadi pewujudan berpikir ilmiah atau pewujudan semangat mencari ilmu pengetahuan; dari perlindungan jiwa (hifz an-nafs) menjadi perlindungan kehormatan manusia (hifz al-karamah al-insaniyah) atau perlindungan hak-hak manusia (hifz huquq al-insaniyah); dari perlindungan agama (hifz ad-din) menjadi perlindungan

${ }^{5}$ Baik oleh rekan-rekan seagamanya yang hidup di dunia mayoritas Muslim maupun minoritas Muslim yang hidup di negara-negara mayoritas non-Muslim di seluruh dunia. Kalau tidak dibuka dengan menggunakan kunci yang tepat, maka pintu tidak akan terbuka atau terbuka tetapi rusak. Baik dalam kondisi pintu tertutup maupun pintu rusak, keduanya akan berakibat kepada nasib umat Islam di seluruh dunia di era globalisasi seperti saat sekarang iniM. Amin Abdullah, "Bangunan Baru Epistemologi Keilmuan Studi Hukum Islam Dalam Merespon Globalisasi" Asy-Syir'ah Jurnal Ilmu Syari'ah dan Hukum, Vol. 46 No. II, Juli-Desember 2012, 327-328

6 Jasser Auda, Maqasid .., 253; 191, istilah 'multimensi' sama dengan 'interkoneksi'.

7 Jasser Auda, Maqasid., .. ,hlm. xxvii

8 Sehingga struktur yang bisa bisa dikembangkan lebih lanjut adalah "struktur multidimensional": tingkat kebutuhan, cakupan aturan, cakupan orang, dan tingkat universalitasnya sesuai dengan dimensinya yang merepresentasikan sudut pandang dan klasifikasi yang sesuai. Jasser Auda, Maqasid., 
kebebasan berkeyakinan (hurriyah al-I'tiqad); dari perlindungan harta kekayaan (hifz al-mal) menjadi pewujudan solidaritas sosial. ${ }^{26}$

b. Konsep baru teori maqasid

Dengan konsep baru yang ditawarkan Auda mengklasifikan maqasid al-syari'ah kedalam tiga level:

a) General maqasid adalah tujuan-tujuan syariah yang keberadaannya dapat ditemukan dalam setiap pembahasan semua bidang hukum Islam, seperti daruriyat dan hajiyat dan maqasid baru, seperti keadilan dan keringanan.

b) Parsial maqasid adalah tujuan-tujuan syariah yang ditemukan dalam satu bagian hukum Islam, seperti perlindungan anak dalam hukum keluarga, pencegahan kejahatan dalam hukum pidana, pencegahan monopoli dalam hukum bisnis

c) Spesifik maqasid adalah alasan" (al-illah) atau tujuan (al-gayah) dari teks atau hukum tertentu atau maqasid dibalik nash atau aturan khusus, seperti tujuansyariah dalam menemukan kebenaran dalam persaksian di pengadilan, maqasid memberi makan kepada kaum fakir dalam hal larangan menyimpan makanan di hari Raya Idul Fitri.

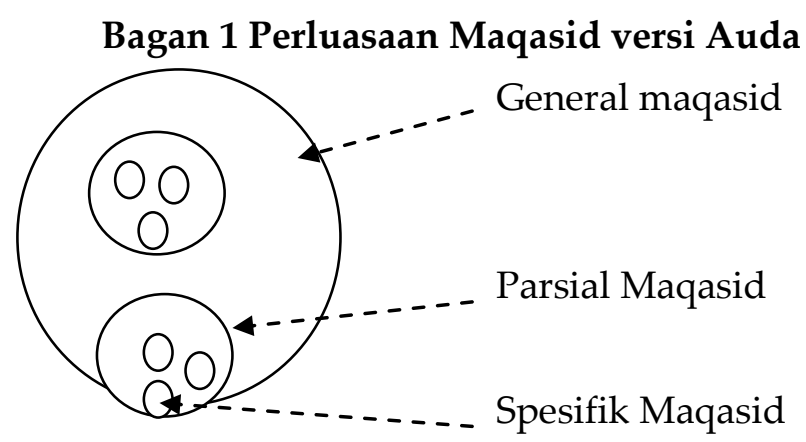

\section{Kritik Terhadap Pemikiran Fikih Tradisional}

Problem utama dalam pengembangan fikih yang responsif adalah kuatnya tradisi mazhab dalam hukum Islam, bahkan antar satu mazhab dengan mazhab yang lain saling menyalahkan, kemudian puncaknya adalah ditutupnya pintu ijtihad. Padahal hanya dengan ijtihad, hukum Islam bisa menjawab pesoalan-persoalan kekinian yang terus mengalir deras seiring dengan dengan perkembangan peradaban manusia. Dengan berhentinya wahyu, persoalanpersoalan baru menuntut jawaban-jawaban yang memadai. Di sisi lain para ahli hukum Islam masih sibuk dengan perbedaan pendapat, saling menyalahkan, bahkan saling mengkafirkan. 
FITRAH Jurnal Kajian Ilmu-ilmu Keislaman

Vol. 05 No. 1 Juni 2019

Dalam menyikapi perbedaan yang sulit adalah menyadari dan menerima perbedaan sebagai sebuah kenyatana dan kelaziman, sehingga perbedaan itu bukan ancaman, namun sesuatu yang natural. Menyikapi silang sengkarut perbedaan fikih Jasser Auda mengajak semua orang untuk mengubah sikap saling menyalahkan pendapat kelompok lain menjadi 'membenarkan semua Pendapat.' Perubahan sikap ini bisa dilakukan dengan mempertanyakan kembali apakah ijtihad itu 'wahyu' atau 'penafsiran terhadap wahyu'.

a. Ijtihad itu wahyu?

Umumnya para ahli hukum Islam mendefiniskan fikih sebagai hasil pemahaman manusia. Namun seringkali metode figh dan hasilnya dianggap sebagai 'hukum Tuhan' atau perintah Tuhan demi kepentingan segelintir orang. Memang betul bahwa nash (al-Qur'an dan hadis) adalah wahyu, namun penafsirannya selalu tunduk pada pemahaman dan pandangan dunia mufasir.

Begitu juga dengan hasil ijtihad sering dikategorikan sebagai wahyu, padahal definisi dan keabsahan metode ijtihad bergantung pada pendapat yang beragam. Misalnya ijma' (konsensus), sekalipun banyak perbedaan perihal batasan ijma' (konsensus), para ulama menganggapnya sebagai dalil qath'i seperti nash, orang-orang yang menolaknya dianggap 'kafir.' Orangorang yang telah terbiasa dengan literatur fikih klasik akan paham bahwa ijma' sering diklaim untuk mendukung atau menolak satu pendapat. Ibn Taymiah misalnya mengkritik karya Ibn Hazm Maratib Al-Ijma' dalam karyanya Naqd maratib al-ijma'. Ibn Taymiah menyatakan ketidaksesuaian klaim ijma' Ibn Hazm terhadap sejumlah masalah-masalah ijtihad. ${ }^{9}$

Hal ini menunjukkan bahwa posisi qathi terhadap ijma' terbantahkan. Ijma' bukan merupakan sumber hukum, ia hanyalah mekanisme konsultasi, dalam konteks terminologi pendekatan sistem, membuat keputusan dengan melibatkan banyak partisipan. Namun sekarang ijma' digunakan untuk memonopoli fatwa pada kelompok tertentu. Menurut Audah, dalam konteks modern prinsip ijma' bisa digunakan untuk menyusun fatwa kolektif, apalagi dengan perkembangan TI yang sangat pesat.

b. Membedakan wahyu dengan penafsiran

Posisi mujtahid dalam literatur hukum Islam dikenal dengan almusawwibah (validator), aturan-aturan yang dihasilkan para mujtahid adalah

\footnotetext{
${ }_{9}$ Jasser Auda, Maqasid...., hlm. 192-193
} 
asumsi (zhan), karena mereka berusaha dengan sekuat tenaga untuk memahami nash. Uraian ini semakin memperjelas mana ide manusia dan mana nash. Di samping itu sebagai validator mereka menyatakan bahwa pendapat-pendapat hukum yang berbeda tetap dianggap benar (shawab), sehingga dalam konteks fiqih ada banyak 'kebenaran.' Pemikiran seperti ini banyak mempengaruhi ulama fikih masa pertengahan, seperti Ibn Rusyd, Abu Hasan al-Asy'ari, dll.

Pendekatan sistem terhadap hukum Islam, memandang hukum Islam sebagai sebuah sistem dalam pengertian ontologis. Sehingga penerapan pendekatan sistem indentik dengan al-mushawwibah, aturan-aturan hukum yang dihasilkan oleh faqih kemungkinan besar 'benar', aturan-aturan yang berbeda juga mungkin benar. Untuk membedakan wahyu dengan 'fiqih' atau pemahaman, bisa dilihat hubungan antara fiqih, syari'ah, 'urf dan qanun. Fiqih berasal dari 'wahyu' menjadi ilmu tentang pemahaman manusia terhadap wahyu, sehingga posisinya berada di luar lingkaran wahyu. Oleh sebab itu tidak ada pendapat fiqih yang masuk dalam masalah 'teologi.' Bahkan jikalau fikih tidak bisa diubah, maka ia termasuk dalam kategori historisisme yang sangat dikecam oleh Islam. ${ }^{10}$

\section{Menuju Pendekatan Holistik}

Upaya untuk mengintrodusir pendekatan holistik dalam hukum Islam sebenarnya sudah dirintis oleh para ulama, namun belum menunjukkan keberhasilan karena dua hal: pertama, Sifat Zhanni Pada Dalil Tunggal; sebagian ulama telah memperingatkan keterbatasan atau bahkan kegagalan pendekatan reduksionis dan atomis yang selalu digunakan sebagai metodologi keilmuan Islam. ${ }^{11}$ Sayangnya kritik tersebut hanya didasarkan pada sifat zhanni berhadapan dengan $q a t h^{\prime} i$, yang lagi-lagi terjebak pada pendekatan biner. ${ }^{12}$

10 Kesalahan pengikut historisisme adalah mereka telah menganalogikan teks dan karangan-karangan manusia yang dihasilkan di tengah peradaban dan konsep-konsep yang berubah, dengan teks Tuhan. Ini bertentangan dengan keimanan, Auda, Maqasid..., 34

11 Pendekatan atomis adalah pendekatan yang ingin memisahkan antara satu bagian dengan bagian lainnya yang terkait, dalam konteks ushul fikih, mengandalkan satu nash untuk dalam menghadapi kasus dengan meninggalkan nash-nash lain yang terkait, sehingga bisa dikatakan atomistik adalah lawan kata dari holistik.

12 Ar-Razi dalam al-Mahsul meringkas pendapat para faqih yang menyatakan mengapa dalil al-khitab an-nash (bukti linguistik) hanya bersifat zhanni: 1) Ada kemungkinan bahwa aturanaturan yang kita simpulkan dari nash tunggal terbatas pada situasi tertentu tanpa sepengetahuan kita, 2) Kemungkinan pernyataan nash tunggal adalah metafor, 3) Tatabahasa Arab sampai kepada kita melalui puisi Arab kuno, yang diriwayatkan melalui perawi tunggal. 4) Ada kemungkinan bahwa satu atau lebih kata dalam nash tunggal mengandung banyak arti, 4) Ada kemungkinan 
FITRAH Jurnal Kajian Ilmu-ilmu Keislaman

Vol. 05 No. 1 Juni 2019

Kedua, Kelemahan 'Sebab' pada teori Tradisionalis dan Modernis. Perdebatan para teolog berkisar pada prinsip perbuatan Tuhan. Para ulama membagi perbuatan Tuhan ke dalam perbuatan makhluk (fi'l al-khalq) dan perbuatan hukum (fi'l at-Tasyri'i). Kelompok pertama, didominasi mayoritas fuqaha' - Asy'ari, Salafi, Zahiri, menyatakan bahwa perbuatan Tuhan terkait perbuatan makhluk di atas 'sebab' atau sering dikenal dengan "Teori Kekuasaan Tuhan". Namun sebagian mereka menetapkan 'illat pada perbuatan Tuhan dalam hukum, sehingga ada hubungan antara hukum dengan illat. Kelompok kedua, Mu'tazilah, Syi'ah dan Maturidiyah percaya adanya 'sebab' terhadap semua perbuatan Tuhan atau sering dikenal dengan Teori Keadilan Tuhan. Oleh karena itu sampai hari ini cara berpikir 'sebab' mendominasi metodologi hukum Islam pada semua mazhab.

Di luar dua pendapat tersebut, ada sebagain ulama yang menekankan pentingnya dalil kulli. Namun dalil ini belum banyak berpengaruh terhadap metodologi itu sendiri, karena kuatnya dominasi cara berpikir 'sebab' baik dalam teologi maupun hukum. Al-Juwaini pernah mengusulkan pentingnya pemikiran holistik dalam hukum Islam dengan menawarkan qiyas kulli, Syatibi juga mengusulkan fitur holistik/ universal menjadi dasar hukum Islam, ia juga memberi prioritas terhadap al-qawaid al-kulliyah daripada ahad al-juziyyat. Namun tawaran-tawaran ini tidak mendapatkan tempat dalam tradisi keilmuwan Islam.

Padahal tokoh-tokoh Islam modern telah menunjukkan kekurangan pendekatan parsial dan individual terhadap hukum Islam. Ibn Asyur misalnya, mencoba memperbaiki kelemahan pendekatan individual dengan memberikan prioritas terhadap maqasid masyarakat daripada individu, Rasyid Ridha memasukkan reformasi masyarakat dan hak asasi ke dalam teori maqasidnya, Taha Alwani memasukkan pembangunan peradaban di muka bumi dalam maqasidnya, begitu juga dengan Yusuf Qardawi yang memasukkan pembangunan bangsa dan keluarga dalam maqasid universalnya. Namun lagilagi sampai abad 20, modernisme Islam belum bisa keluar dari persoalan 'sebab' dari teologi umat. Baru setelah abad itu implementasi teori holistik mewujud dalam tafsir tematik karya Hasan Turabi, Tafsir at-Tauhidi. Ia menjelaskan bahwa pendekatan tauhidi (integrasi) atau kulli (holistik) mencakup sejumlah metode

pernyataan itu mengandung makna tersembunyi yang tidak kita ketahui. Latar belakang filosof Ar-Razi telah memberikan kontribusi yang mendalam terhadap klaim qath'i pada dalil nash tunggal, namun ia gagal menjelaskan problem utama pendekatan nash tunggal, 'sebab" (atomistik, biner). 
pada setiap level. Pada level bahasa, pendekatan ini meliputi bahasa Al-Qu'an sebagai integrasi, menyatukan bahasa al-Qur'an dan bahasa penerima pesan saat wahyu diturunkan. Pada level pengetahuan manusia, ia mencakup pendekatan holistik baik terhadap dunia materi maupun immateri, dengan semua unsur dan aturan yang menyertainya. Pada level topik, mencakup tema-tema lintas ayat dan menyangkut kehidupan sehari-hari. Pendekatan ini juga menyatukan hukum dengan moral dan spiritualitas.

\section{Ilmu Kalam Holistik}

Pendekatan holistik, tidak hanya ditawarkan untuk hukum Islam tetapi juga untuk ilmu kalam (teologi). Filsafat holistik (sistem) ingin mendekatkan 'sebab-akibat' kedalam 'rangkaian yang saling terkait' dalam memahami dunia ini. Dalam filsafat sistem, prinsip sebab akibat dikritik beserta pandanganpandangan teologisnya.

Dengan prinsip holistik, Auda menawarkan tidak hanya untuk memperbarui hukum Islam tetapi juga ilmu kalam. Sudah lazim dikatakan bahwa dalil penciptaan (dalil ikhtira') adalah 'Setiap perbuatan pasti ada tujuan' bukan 'setiap perbuatan ada 'Sebabnya'. Sedangkan dalil pemeliharaan (dalil ri'ayah) adalah keseimbangan dan persaudaraan manusia terhadap ekosistem bumi dan subsistem, bukan 'pemeliharaan langsung'. Begitu juga dengan dalil wujud adalah desain yang sistematik dan integratif alam semesta, sebagaimana kita pahami saat ini, bukan 'Sebab Pertama' sebagaimana diintrodusir oleh Muhammad Abduh. Ilmu Kalam holistik mensyaratkan adanya keterbukaan dan self renewal. Terbuka untuk mengambil manfaat dari ilmu-ilmu lain-bukan hanya ilmu keislaman an sich. Self renewal adalah kesediaan untuk memperbarui, mengoreksi diri dan berpikir multimensi. ${ }^{13}$ Pentingnya Kalam Holistik ini karena Ilmu Kalam Klasik tidak mampu menjelaskan permasalahanpermasalahan kemanusiaan modern, misalnya bagaimana cara memahami Tuhan yang mampu menghapus kemiskinan, baik struktural maupun kultural, bagaimana pendidikan akhlak yang dapat menghalangi godaan untuk melakukan kekerasan atas nama agama, kejahatan narkoba, dan penyakit sosial lainnya? ${ }^{14}$

\footnotetext{
${ }^{13}$ Jasser Auda, Maqasid...., hlm. 201, 211

${ }^{14}$ Amin Abdullah, "Fikih dan Kalam Sosial Era Kontemporer: Perjumpaan Ulum al-Din dan Sains Modern Menuju Fresh Ijtihad" dalam Islam Nusantara, (Bandung: Teraju, 2015), hlm. 75
} 
FITRAH Jurnal Kajian Ilmu-ilmu Keislaman

Vol. 05 No. 1 Juni 2019

\section{Menuju Keterbukaan dan Pembaharuan Diri}

Teori sistem akan tetap hidup apabila tetap menjaga keterbukaan dan pembaharuan diri. Oleh karena itu untuk mengubah hukum Islam, melalui dua langkah berikut:

a. Mengubah aturan-aturan fikih dengan mengubah budaya kognisi mujtahid

Pandangan dunia adalah seperangkat dugaan (pengetahuan), sistem keyakinan atau cermin pengalaman yang kita gunakan untuk memahami dunia. Sehingga pandangan dunia adalah kumpulan sejumlah faktor untuk membentuk pemahaman manusia terhadap dunia, misalnya Tuhan, dunia manusia, kehidupan sesudah mati, pengetahuan, moral, sejarah, mitos, doktrin, masyarakat, politik, biologi, psikologi, ruang dan waktu adalah di antara faktor-faktor yang mempengaruhi cara pandang seseorang.

Teori tersebut menunjukkan bahwa pandangan dunia seseorang dibentuk oleh semua hal yang ada di sekitar kita, dengan kata 'budaya' dalam pengertian yang luas, pandangan dunia adalah representasi budaya kognisi. Dalam ushul fiqih, urf adalah bentuk interaksi hukum Islam dengan dunia luar. Dalam ushul fiqih Hanafi, dikenal teori "apa yang ada dalam hukum adat (urf) sama secara implisit sama dengan nash eksplisit." Mazhab-mazhab yang lain menyetujui pendapat ini, bahwa jika ada ketentuan hukum dalam nash, maka berlaku hukum adat. Karena tujuan penggunaan urf sebagai teori ushul fiqih adalah mengakomodasi kondisi sebagian masyarakat yang berbeda adat Arab. Namun dalam prakteknya, penerapan 'urf dalam fikih sangat terbatas, seperti nilai mahar, membuka atau menutup kepala laki-laki, dan bentuk zakat fitrah (kurma, kismis, gandum). Sedikitnya praktek 'urf ini tidak mencerminkan keragaman kehidupan manusia, selain dunia Arab abad pertengahan. Sehingga banyak hukum-hukum fiqih tetap menggunakan 'urf Arab pada awal abad kedua atau ketiga, atau pandangan dunia Arab.

Berdasarkan sifat kognisi hukum yang ditawarkan tersebut, 'urf dalam teori hukum Islam adalah 'urf sebagaimana pandangan dunia mujtahid, selama ia tidak bertentangan dengan maqasid syari'ah. Oleh sebab itu pandangan dunia 'mujtahid' yang ditawarkan di sini adalah perluasan metode 'urf untuk mengakomodir perubahan-perubahan adat orang Arab asli awal pada abad kedua dan tiga. 
Seorang mujtahid disamping menguasai ilmu al-Qur'an dan hadis ${ }^{15}$ juga harus menguasai ilmu-ilmu pengetahuan lain, sehingga ia menjadi mujtahid yang 'kompeten' untuk menghasilkan rumusan fikih yang akurat. Tawaran ini akan memiliki pengaruh sebagai berikut: pertama, perubahan pandangan dunia mujtahid akan mengurangi kecendrungan literalis - kecuali dalam fiqih ibadah, sekalipun demikian dimensi maqasid harus muncul dalam bidang ibadah. Kedua perubahan padangan dunia mujtahid juga akan membuka sistem hukum Islam terhadap temuan-temuan baru dalam ilmu sosial dan ilmu alam. Rumusan-rumusan fikih, baik waqi'i maupun fikih kontemporer tidak lagi bisa bergantung klaim mujtahid an sich, tanpa bantuan penelitianpenelitian ilmu sosial dan ilmu alam. Misalnya dalam masalah usia baligh, seorang mujtahid seharusnya berkosultasi dengan dokter, dalam konteks ini "data empiris harus menjadi hujjah/dalil (otoritas)" sekalipun menurut logika tradisional ia bersifat zhanni. Hal yang sama juga berlaku untuk ilmu psikologi untuk mendefinisikan konsep dan usia pemisahan antara laki-laki dan perempuan. Benar bahwa ilmu pengetahuan terus berkembang, dan ini pasti menuntut kita untuk memperbaharui keputusan-keputusan dan jawaban ilmiah yang kita miliki. Karena evolusi ilmu pengetahuan adalah bagian dari evolusi ilmiah pandangan dunia mujtahid, sehigga hal itu harus tercermin dalam hukum. Inilah prinsip keterbukaan dalam sistem hukum Islam.

\section{Bagan 2}

Wordview Mujtahid sebagai faktor utama dalam menghasilkan produk

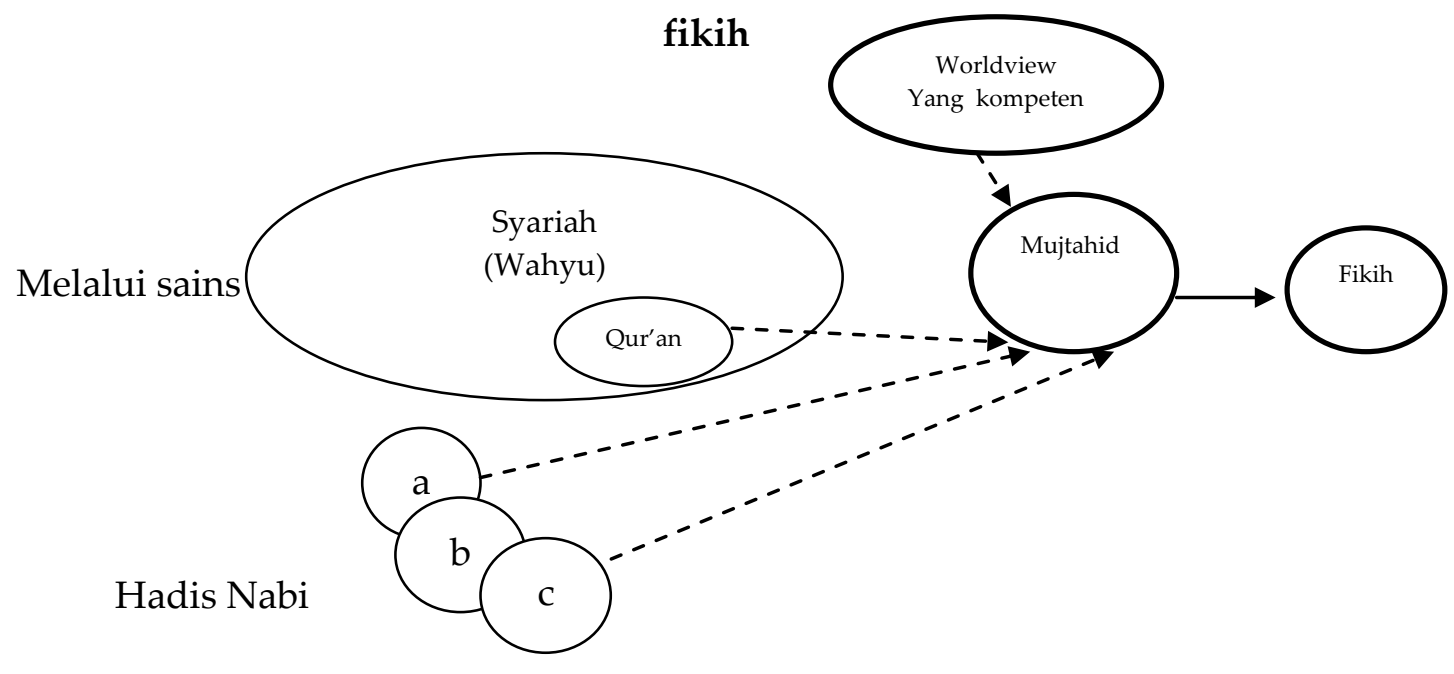

${ }^{15}$ Di samping pengetahuan tentang al-Qur'an dan hadis, figh waqi'i, persyaratan lain seseorang menjadi mujtahid silahkan dicek dalam Ibn Qayyim, Thuruq al-Hukmiyyah, vo. I: 5 
FITRAH Jurnal Kajian Ilmu-ilmu Keislaman

Vol. 05 No. 1 Juni 2019

b. 'Pembaruan Diri' melalui keterbukaan

Melalui keterbukaan terhadap filsafat, mujtahid bisa melakukan pembaharuan terhadap hukum Islam. Karena filsafat termasuk salah satu kompetensi yang harus dikuasai oleh mujtahid. Dasar-dasar hukum Islam indentik dengan filsafat hukum Islam, sehingga dasar-dasar itu terbuka terhadap penyelidikan filosofis, yang berkembang bersama perkembangan pengetahuan manusia secara umum.

Sayangnya sejarah mencatat mayoritas ulama (mazhab fikih tradisional) menolak upaya penggunanaan filsafat dalam mengembangkan fikih atau ilmu-ilmu keislaman secara umum. Dengan mengutip contoh-contoh teori metafisika Yunani-yang bertolak belakang dengan akidah mayoritassebagian ulama mengeluarkan fatwa larangan mempelajari dan mengajarkan filsafat di lembaga-lembaga pendidikan. Dengan dasar fatwa ini, hanya ada pilihan mengikuti filsafat atau mengikuti jalan al-Qur'an, kemudian para filosof dituduh murtad, karya-karyanya dilarang untuk beredar, dan dipelajari. Sekalipun demikian sebagian ahli hukum Islam menolak metafisika Yunani, tetapi menerima logikanya. Kita mengenal al-Ghazali yang menyerang filosof melalui karyanya tahafut al-falasifah, namun dalam beberapa kesempatan al-Ghazali juga menggunakan logika Aristoteles untuk menjelaskan eksistensi Tuhan dalam al-Qur'an. Ia bahkan menyatakan logika adalah pintu masuk semua cabang ilmu pengetahuan, yang tanpanya akan ada kompetensi ilmuwan di semua cabang ilmu pengetahuan. Saat menjelaskan ayat al-Qur'an "jika ada tuhan lain di langit atau di bumi selain Allah, tuhan-tuhan itu akan bertengkar, al-Ghazali terbukti menggunakan Modus Ponnes dan Modus Tollens-logika Aristoteles. Modus Tollen: "lebih dari satu Tuhan akan mengakibatkan kekacauan, karena tidak ada kekacauan, maka hanya ada satu Tuhan". Dengan demikian pelarangan para ulama klasik terhadap filsafat sama dengan fatwa kelompok neo-literalis yang membolehkan mengambil ilmu pengetahian hanya pada bidang teknologi, bukan ilmu sosial dan budaya. Artinya di satu sisi mereka mereka melarang filsafat, namun di sisi lain mereka menerima dan mengambil manfaat dari filsafat.

Berbeda dengan mayoritas ilmuwan muslim, Ibn Rusyd memiliki pendirian yang sangat terbuka terhadap ilmu budaya. Di samping didasari perintah al-Qur'an agar setiap muslim selalu menggunakan akal dan 
memikirkan ciptaan-Nya, Ibnu Rusyd berusaha dengan sekuat tenaga untuk memanfaatkan semua bentuk penalaran filosofis ${ }^{16}$. Jalan keluar yang ditawarkan olehnya mempertemukan pertentangan tampak antara akal dan nash dengan menafsirkan kembali nash sepanjang diperbolehkan oleh bahasa agar sesuai dengan kesimpulan akal. Ia juga menyalahkan al-Ghazali dan ilmuwan lain yang telah menuduh para filosof sebagai murtad tanpa berusaha untuk memahami posisi filosof. Metode Ibnu Rusyd untuk mempertemukan nash dan akal, keterbukaan terhadap ilmu lain, penolakannya terhadap tuduhan murtad bagi filosof, ajakannya untuk menggunakan filsafat memiliki pengaruh yang sangat kuat terhadap gerakan reformis Islam modern. Oleh karena itu agar sistem hukum Islam bisa melakukan pembaharuan diri, perlu mengadopsi keterbukaan Ibn Rusyd terhadap penyelidikan filosofis dan memperluas keterbukaan itu dalam teori-teori hukum Islam.

\section{Menuju Multidimensi}

Dalam teori hukum Islam tradisional, dalil diklasifikan menjadi, qath'i dan zhanni: Wilayah Qath'i. Qath'i dan zhanni adalah dikhotomi yang mengakar kuat dalam metodologi dan mazhab hukum Islam ${ }^{17}$. Dalam fikih sebagian dalil dianggap sah, hanya karena perluasan cakupan qath'i, Ali Jum'ah misalnya menyatakan bahwa ijma' adalah dalil qath'i, sehingga sering mengabaikan pemahaman implisit (istihsan). ${ }^{18}$ Konsep qath'i kemudian lahir dalam berbagai bentuk seperti: Qath'i dilalah (implikasi linguistik), qath'i al-subut (otensitas sejarah), qath'i al-manthiqi (implikasi logis). Bentuk-bentuk ini mengakibatkan munculnya implikasi negatif berikut: Pertama, perintah sharih al-Qur'an dan Hadis diklaim sebagai qath'i (qath'i al-dilalah). Metode istinbath hukum dari nash sharih menghasilkan hukum yang qath'i-sekalipun dengan mengabaikan nash

${ }^{16}$ Keterbukaan Ibn Rusyd terhadap terhadap ilmu pengetahuan ini dilatarbelakangi oleh kondisi keluarganya yang sangat menghargai ilmu pengetahuan dan kondisi sosial masyarakat Andulusia yang sangat terbuka. Nidhal Guessoum, Islam Quantum Question: Reconciling Muslim Tradition and Modern Science, (London: I.B. Tauris, 2011), hlm. xv

17 Pemikiran dikhotomis bermula ketika para ulama ushul mendefinisikan istilah (ta'rif). Cara demikiran jika dirunut dipengaruhi oleh logika Aristoteles. Definisi bisa dengan al-hadd (analisis etimologis); atau al-rasm, deskripsi sifat yang membedakan dengan lainnya, lihat Auda, Maqasid..., hlm. 210

${ }_{18}$ Perhatikan bahwa ijma' itu bukan qath'i sebagaimana Ibn Taymiah mengkritik karya Ibn Hazm Maratib Al-Ijma' dalam karyanya Naqd maratib al-ijma' 
FITRAH Jurnal Kajian Ilmu-ilmu Keislaman

Vol. 05 No. 1 Juni 2019

lain yang juga dianggap qath'i. ${ }^{19}$ Jasser Auda memberikan jalan keluar: bahwa satu penafsiran terhadap perintah dalam hadis nabi tidak harus menghasilkan hukum yang qath'i, namun hanya memiliki konteks spesifik saja yang menyebabkan Nabi mengeluarkan perintah tersebut, bisa konteks ekonomi, politik atau lingkungan.

Dengan cara berpikir bahwa nash sharih harus menjadi qath'i, sementara nash lainnya dianggap zhanni, yang diyakini tidak bisa dihilangkan oleh keraguan, tanpa memikirkan konteksnya masing-masing--perintah-perintah yang ada dalam al-Qur'an dan kumpulan hadis yang dipahami dengan cara berpikir biner ( $q a t h ' i$-zhanni)--akan menghasilkan aturan fikih yang sempit, tidak sesuai dengan konteks, dan pemahaman yang parsial. Kedua, al-Qur'an seluruhnya dan sebagian hadis mutawatir adalah qath'i al-tsubut (secara historis adalah qath'i). Sedangkan dalam menyikapi hadis ada sebagian ulama berpendapat ia adalah qath'I selama disetujui oleh umat. Ibnu Shalah berpendapat bahwa hadis yang disetujui oleh Bukhari dan Muslim adalah hadis shahih (qath'i) karena telah disepkati oleh umat, sehingga tidak mungkin salah (ma'shumah), dan disetujui oleh banyak ulama. Ibnu Taimiyah termasuk ulama yang menggunakan hadis ahad sebagai dalil qath'i. Ia bahkan menggunakannya sebagai dalil-dalil untuk hal-hal terkait pokok ajaran agama (i'tikad), seperti sifat Allah, kelebihan suku Quraish, lagu-lagu Sufi sebagai bid'ah. Padahal berhukum dengan hadis ahad ditentang oleh banyak ulama, karena sanadnya dipertanyakan, dan masalah lainnya. Khalid Abu Fadhl menyebut problem ini adalah klaim empiris, yang sangat sosiologis.

\footnotetext{
${ }^{19}$ Hadis berikut menunjukkan problem qath'I al dilalah: a) Nabi mendengar dua orang bertengkar perihal sewa menyewa lahan, kemudian nabi bersabda, "Jika kamu tetap demikian, jangan menyewakan lahan," (kesimpulannya: menyewakan lahan dilarang), padahal pelarangan itu hanya apabila pertengkaran. b) Wahai Rasulullah, bayi ini adalah anak yang saya kandung, saya susui dari asiku, dan saya dekap setiap hari. Bapaknya menceraikan aku, dan dia mau mengambil anak ini. Rasulullah saw bersabda, "Kamu lebih berhak untuk merawatnya, kecuali kamu menikah lagi." (kes: perceraian itu menghilangkan hak asuh, jika si ibu menikah lagi), padahal perintah nabi itu bukan yang berlaku umum, bisa disesuaikan dengan kondisi yang ada; c) Rasulullah saw bersabda, "Seseorang tidak diwajibkan membayar zakat mal atas kuda yang dimilikinya. Namun jika jumlah kuda mencapai nishab, maka wajib zakat; d) nabi Muhammad saw bersabda, "diyat untuk satu nyawa adalah 100 unta." Syarat diyat 100 unta tergantung pada budaya yang dominan di Arab.
} 


\section{Bagan 3: Bukti Implikasi Logis dan Otensitas Historis menjadi bagian}

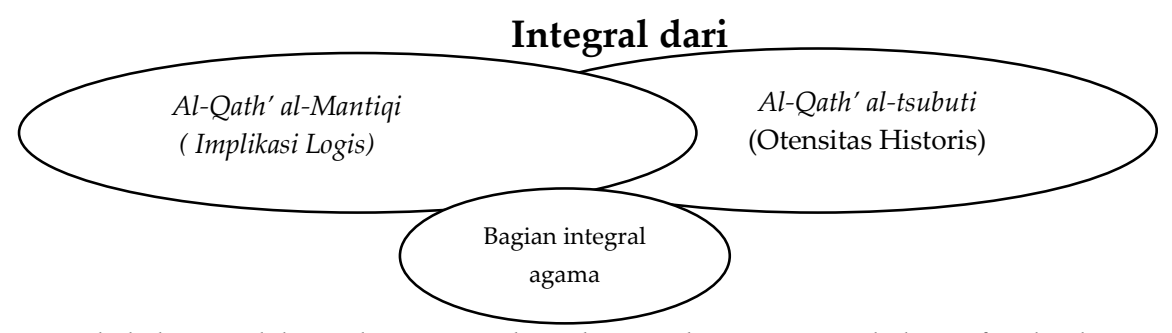

Ketiga, adalah implikasi logis (qath'i al-manthiqi) yang dalam fiqih digunakan untuk menentukan illat dalam qiyas. Namun karena Syi'ah, Mu'tazilah, Zaidiyah dan kelompok tekstual tidak mengakui qiyas, sebagian ulama Sunni merasa kurang nyaman dengan istilah qath'i dalam illat. ${ }^{20}$ Oleh karena itu al-Ghazali menyatakan kerja mujtahid adalah kerja al-mushawwibah, bahwa Tuhan tidak menurunkan keberan tunggal untuk setiap aturan hukum, sehingga yang benar adalah apa yang dipahami oleh mujtahid sebagai kebenaran. Singkat kata, penalaran menggunakan qiyas lebih banyak menggunakan bukti-bukti zhanni daripada qath'i. Sehingga pendekatan biner terhadap konsep qhath'i itu semata-mata sejarah! Matematika dasar menetapkan probabilitas terhadap parameter berdasarkan rangkaian bukti yang mendukungnya. Sehingga ada wilayah "kepastian" (kebenaran) untuk setiap bukti, bukan dikhotomi biner.

\section{Bagan 4, Semua tujuan hukum adalah sah}

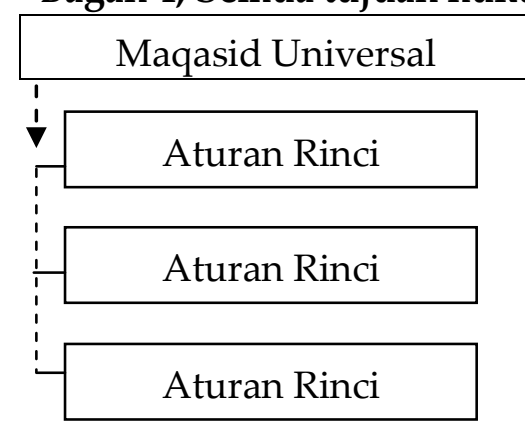

Dengan menggunakan sifat kognitif hukum Islam, semua aturan hukum yang berdasarkan pada maqasid adalah hukum sah.

${ }^{20}$ Al-Ghazali misalnya menulis 6 alasan probabilitas dalam illat: a) kita mengasumsikan sebuah illat untuk aturan fikih yang tidak memiliki illat menurut Allah, b) Sebuah aturan memiliki illat menurut Allah, namun kita salah untuk menyimpulkannya, c) aturan hukum memiliki satu illat menurut Allah, namun kita salah dalam menentukannya, d) aturan hukum memiliki satu illat menurut Tuhan, namun kami salah dalam menambahkan illat, e) kita berhasil mendefinisikan illat untuk satu aturan hukum secara tepat, namun kita salah dalam mengkiyaskan illat tersebut menurut Allah, f) kita salah mengklaim illat khusus di balik aturan hukum hanya dengan akal, tanpa menempatkan porsi yang sesuai. 
FITRAH Jurnal Kajian Ilmu-ilmu Keislaman

Vol. 05 No. 1 Juni 2019

a. Mengubah pertentangan ( $t a^{\prime} a r u d$, ikhtilaf) menggunakan pendekatan multidimensi

Pendekatan multi-dimensi, dikombinasikan dengan pendekatan maqasid memberikan solusi terhadap dilema yang muncul akibat pertentangan dalil. Dua dalil yang 'mungkin bertentangan' bila hanya diterapkan salah satu, seperti perang dan damai, perintah dan larangan, berdiri dan duduk, lakilaki dan perempuan dan lain sebagainya. Jika kita memperluas satu dimensi menjadi dua dimensi, kita akan mampu mendamaikan pertentangan tersebut dan menafsirkan dalil-dalil tersebut dalam konteks unifikasi. Dalam shalat misalnya, harus mengikuti semua yang dicontohkan Nabi saw. Namun karena adanya hadis berbeda-beda sering menyebabkan pertentangan. Namun memahami hadis-hadis ini dengan menggunakan kaca mata tujuan kemudahan (maqsid al-taisir) menunjukkan fleksibilitas dalam masalah-masalah ini. Begitu juga dengan hadis-hadis nasikh mansukh hadis-hadis tentang minuman keras dan riba. Dengan mempertimbangkan tujuannya: "memfasilitasi perubahan bagi kebiasaan masyarakat yang sudah mengakar", maka harus dipahami dalam konteks pentahapan pelaksanaan menuju masyarakat ideal.

Bagan 5: Sifat yang bertentangan pada satu dimensi bisa memberikan kontribusi positif terhadap dimensi lain yang memiliki maqasid yang sama

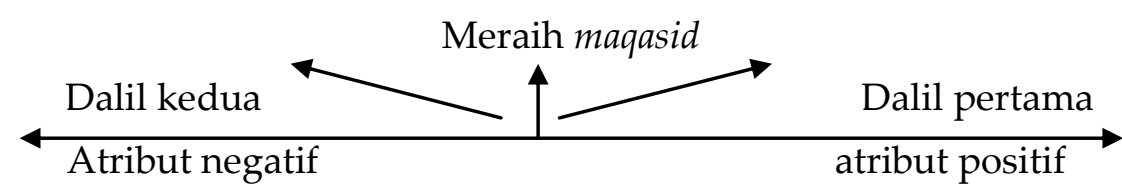

Dengan demikian multidimensi dikombinasi dengan pendekatan maqasid memberikan solusi terhadap dilema dalil yang (tampak) saling bertentangan. Perhatikan (bagan 5), jika kita hanya membatasi pandangan kita hanya pada satu dimensi, kita tidak bisa mendamaikan dalil-dali yang ada. Namun jika kita memperluas dimensi, kita bisa menemukan jalan keluar pertentangan antara dua dalil dan menafsirkannya dalam konteks 'penyatuan. ${ }^{21}$ '

${ }^{21}$ Perhatikan QS 9: 5 (ayat pedang): “apabila sudah habis bulan haram, bunuhlah orang-orang musyrik, dimana saja kamu jumpai, dan tangkaplah mereka..." Konteks ayat ini adalah abad 9 H, yaitu perang antara muslim dan kafir Mekah. Jika dibawa keluar konteksnya, dan ditetapkan untuk dilaksanakan antara muslim dan non di semua tempat dan waktu, akan bertentangan dengan lebih dari 200 ayat lain yang mengajar dialog, kebebasan beragama, saling memaafkan, perdamaian. Mendamaikan antara nash-nash yang berbeda kadang tidak menjadi pilihan. Karena sesuai dengan teori nasakh, sebagian mufasir menyimpulkan bahwa ayat ini menasakh semua ayat yang bertentangan dengan ayat yang diturunkan sebelumnya (mis. Surat al-Kafirun). 


\section{Mencapai Tujuan (Maqasid)}

Implikasi maqasid adalah keniscayaan dalam setiap hukum, dalam konteks filsafat hukum, ketentuan hukum harus memberikan manfaat yang sebesar-besarnya kepada manusia. Jhering menyerukan untuk menggantikan hukum mekanik-kausalitas menjadi hukum bertujuan (law of purposes). Sayangnya seruan ini sulit mengubah cara pandang yang sudah mengakar pada metodologi hukum positif. Inilah pentingya maqasid sebagai komponen penting dalam filsafat hukum. Dalam konteks hukum Islam, menafsirkan ayat-ayat hukum dengan pendekatan maqasidi telah diimplementasikan dalam tafsir tematik. Dengan pendekatan tematik, prinsip dan nilai-nilai moral seolah membiarkan al-Qur'an dalam kesatupaduan (unified whole). Hal yang sama bisa diterapkan untuk hadis. Pendekatan maqasidi dalam hadis akan menemukan kembali konteks yang hilang. Karena kebanyakan hadis terdiri dari satu atau dua kalimat, atau jawaban terhadap satu atau dua pertanyaan, tanpa ada elaborasi historis, politis, ekonomi atau lingkungan. Di samping itu merealisasikan maqasid itu tidak hanya berlaku untuk metode ushul tertentu (qiyas, istihsan, istishhab, syad dari'ah, 'urf) - sebagaimana teori ushul tradisional dan modern-- namun menjadi tujuan utama semua metode ijtihad. Di samping itu dari sudut pandang teori sistem, merelisasikan maqasid itu menjaga: keterbukaan, pembaharuan, dan fleksibilitas dalam sistem hukum Islam.

\section{KESIMPULAN}

Pendekatan maqasid terhadap hukum Islam adalah pendekatan holistik, pendekatan yang merujuk pada prinsip-prinsip umum (commnon ground) yang tidak terbatas pada satu nash atau satu dalil tertentu, namun merujuk pada semua nash atau semua dalil (multidimenasi) dan keutuhan, keterbukaan terhadap ilmu-ilmu lain (sains, sosial dan filsafat), pertentangan antar dalil, qath'i zhanni, sebab akibat, bisa dijembatani, bahkan hukum Islam bisa berkontribusi dalam masalah-masalah kontemporer seperti peran perempuan, hak asasi dan lain sebagainya. Dengan pendekatan ini kelemahan-kelemahan pendekatan biner, atomistis, reduksionis dan pendekatan historis bisa dicarikan jalan keluarnya. 
FITRAH Jurnal Kajian Ilmu-ilmu Keislaman

Vol. 05 No. 1 Juni 2019

\section{DAFTAR PUSTAKA}

Abdullah, M. Amin, "Bangunan Baru Epistemologi Keilmuan Studi Hukum Islam Dalam Merespon Globalisasi" Asy-Syir'ah Jurnal Ilmu Syari'ah dan Hukum, Vol. 46 No. II, Juli-Desember 2012

"Fikih dan Kalam Sosial Era Kontemporer: Perjumpaan Ulum al-Din dan Sains Modern Menuju Fresh Ijtihad" dalam Islam Nusantara, (Bandung: Teraju, 2015)

Auda, Jasser, Maqasid al-Syariah as Philosophy of Islamic Law: a Systems Approach (London: The International Institute of Islamic Thought, 2008)

Guessoum, Nidhal, Islam Quantum Question: Reconciling Muslim Tradition and Modern Science, (London: I.B. Tauris, 2011), xv

Ibn Qayyim, Thuruq al-Hukmiyyah, Dar Ibn Jauzi, vol. I: 5 